Article

\title{
Investigation of Dimension Stone on the Island Brač-Geophysical Approach to Rock Mass Quality Assessment
}

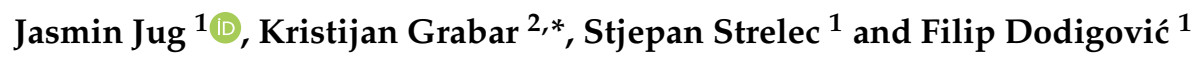 \\ 1 Faculty of Geotechnical Engineering, University of Zagreb, Hallerova aleja 7, Varaždin 42000, Croatia; \\ jasmin.jug@gfv.unizg.hr (J.J.); stjepan.strelec@gfv.unizg.hr (S.S.); filip.dodigovic@gfv.unizg.hr (F.D.) \\ 2 SPP d.o.o., Trstenjakova 3, Varaždin 42000, Croatia \\ * Correspondence: kristijan@spp.hr; Tel.: +385-42-203302
}

Received: 14 February 2020; Accepted: 19 March 2020; Published: 21 March 2020

check for updates

\begin{abstract}
A site located on the island of Brač is known in history for world-famous architectural stone and stone mining, dating all the way back to ancient Greek and Roman times. The most famous building constructed from the stone from Brač is the Diocletian Cesar Palace in the town Split. Prospective new locations for quarries are still required because the demand for the stone from the island is still high. This paper presents a review of undertaken geophysical investigations, as well as engineering geologic site prospection, with the purpose of determining if the rock mass quality is suitable for the mining of massive blocks needed for an architectural purpose-dimension stones. Several surface noninvasive geophysical methods were applied on the site, comprising of two seismic methods, multichannel analysis of surface waves (MASW) and shallow refraction seismic (SRS) electrical methods of electrical resistivity tomography (ERT), as well as electromagnetic exploration with ground penetrating radar (GPR). Results of geophysical investigations were compared to the engineering geologic prospection results, as well to the visible rock mass structure and observed discontinuities on the neighboring existing open mine quarry. Rock mass was classified into three categories according to its suitability for dimension stone exploitation. Each category is defined by compressional and shear seismic velocities as well as electrical resistivity. It has been found that even small changes in moisture content within the large monolithic rock mass can influence measured values of electrical resistivity. In the investigated area, dimension stone quarrying is advisable if the rock mass has values of resistivity higher than $3000 \Omega \mathrm{m}$, as well as compressional seismic velocities higher than $3000 \mathrm{~m} / \mathrm{s}$ and shear wave velocities higher than $1500 \mathrm{~m} / \mathrm{s}$. Georadar was found to be a good tool for the visual determination of fissured systems, and was used to confirm findings from other geophysical methods.
\end{abstract}

Keywords: surface geophysics; MASW; SRS; ERT; GPR; rock mass quality; dimension stone

\section{Introduction}

The main purpose of all undertaken explorations was to evaluate the location's acceptability for future exploitation of the architectural structural stone, in the manner of extraction of dimension stones [1]. The research site is located in the Republic of Croatia, on the island of Brač, the largest island of central Dalmatia. The area spans over 3 hectares, the terrain elevation is $320 \mathrm{~m}$ above sea level, and the closest inhabited place, Donji Humac, is approximately $660 \mathrm{~m}$ northwest from the site. The geographical location of the research site is shown in Figure 1. To consider rock mass interesting from the point of view of extracting a dimension stone, a large supply of mass with similar texture and color should be confirmed. From the economical perspective of dimension stone mining, the strength and deformation properties of the analyzed jointed mass are very important [2]. 


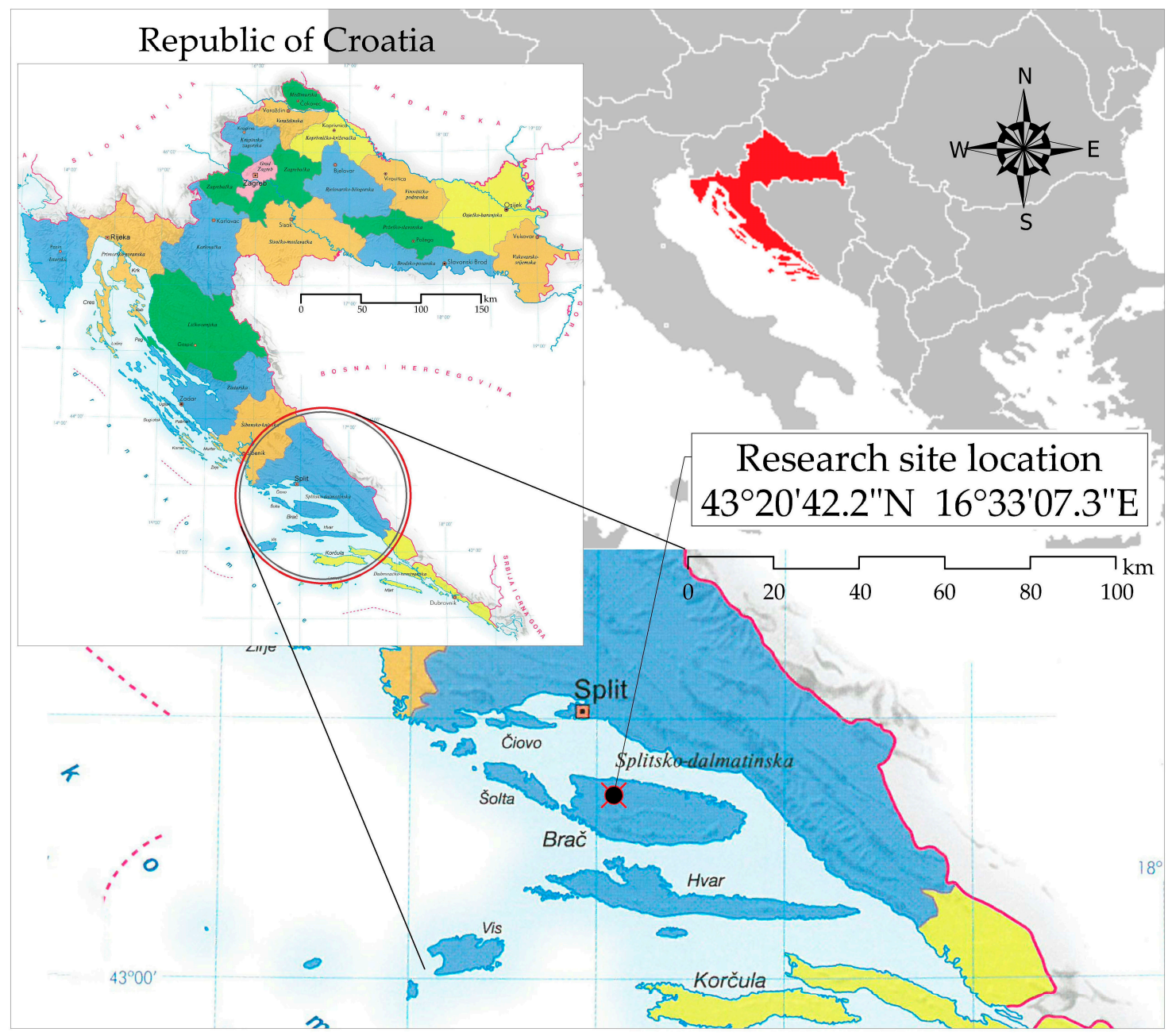

Figure 1. Research site location on the island of Brač.

Investigation works comprise geological surveys and geophysical explorations. Geological prospection includes engineering geologic map creation at an appropriate scale, showing all the available geological elements [3], such as bedding planes, folds and shear zones as well as geological boundaries visible form the terrain surface. Deeper rock mass quality was assessed by geophysical profiling with a planned depth resolution of 20-30 m [4]. Altogether, four seismic profiles were recorded, Seis-1 to Seis-4, with dispositive lengths of $69 \mathrm{~m}$, applying two seismic techniques, multichannel analysis of surface waves (MASW) (Vs) and shallow refraction seismic (SRS) (Vp), two electrical resistivity tomography (ERT) profiles, each $277.3 \mathrm{~m}$ in length, and six georadar (GPR) radargrams of 100 to $300 \mathrm{~m}$ in length. Westward, in the near vicinity of the investigated site, is an operational stone quarry. Stone blocks from the neighboring quarry vary in quality. For the purpose of this investigation, the terrain's surface was partially cleared of vegetation so that the geophysical profiles could be laid down. In conclusion, the site's suitability for mining applications was primarily based on the result of geophysical explorations distributed in profiles as in Figure 2. All named investigative works were done in October 2019.

Relevant structural properties of dimension blocks were defined through a single criterion-an absence of structural and macro discontinuities [5]. Other desired parameters, like color and texture, were not considered in this work. Geophysical methods are considered to be helpful to define macro discontinuities, fractures and fractured zones [6]. Successful explorations with the use of georadar are documented as a single geophysics addition to geological mapping and core drilling [7]. 
The usual way of assessing prospective dimension stone locations is by the basic geological tools of mapping and diamond core drilling [6]. As presented in this paper, secondary surface deposits can mask the entire process of geological mapping, so insight into deeper rock formations could not be acquired [8]. In this case study, rock mass structural elements could only be acquired at Research Plot 1 and only on a very few available rock outcrops. Adjoining the investigation plot there is an open mine with visible artificial cutting lines, thus enabling data from geophysical explorations to be compared, corelated and calibrated. For complete insight in terms of color variations or textural variations, boreholes are needed.

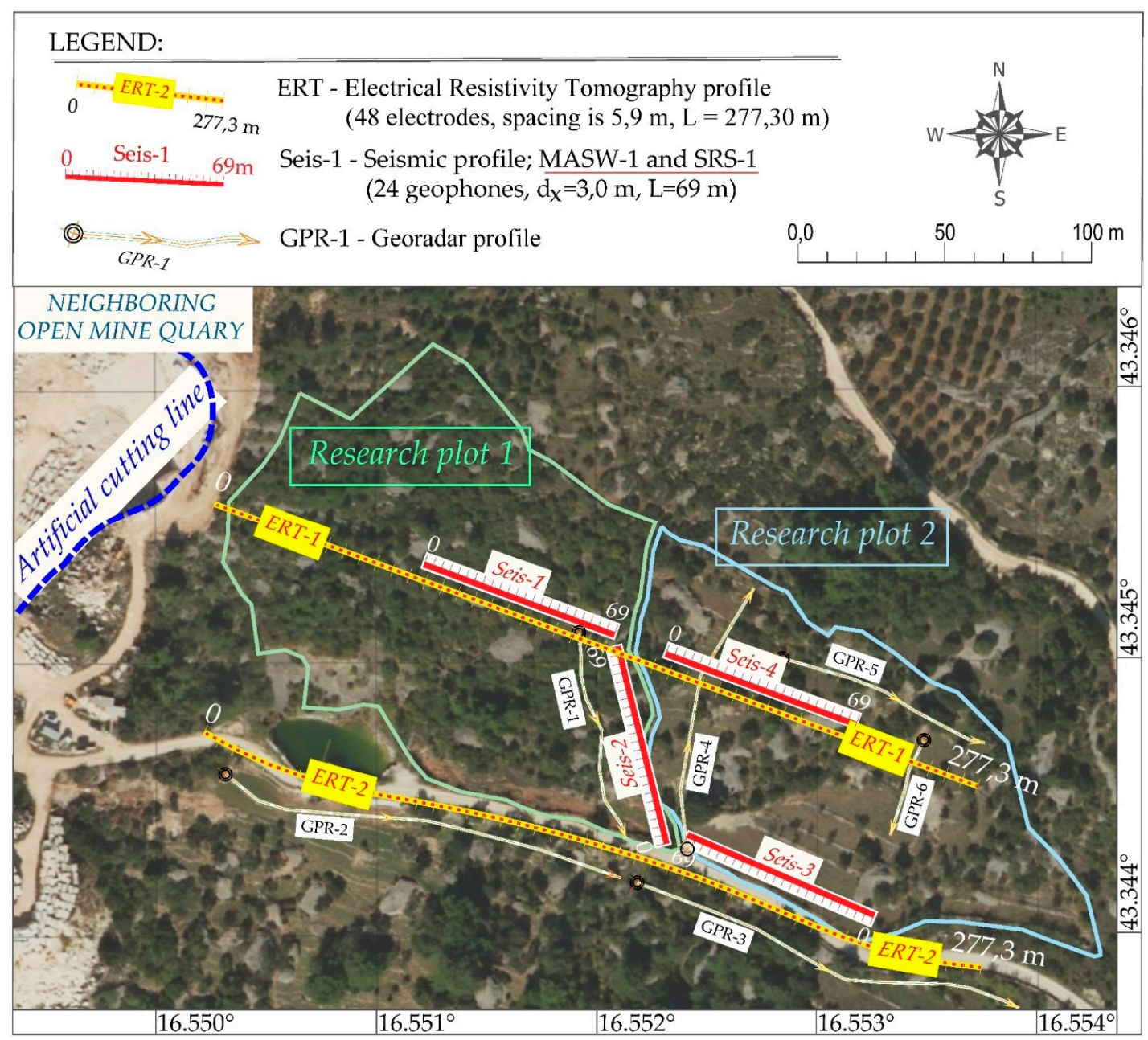

Figure 2. Geophysical profiles distributed on the two research plot areas. The profiles are mainly positioned around the two parallel profiles defined with electrical resistivity tomography (ERT-1 and ERT-2) profiles. The position of the neighboring quarry on the west side is also labeled.

\section{Geological Properties of Investigated Area}

The researched area is relatively well investigated in the geological sense, as mining on the island is well established. Several references regarding the geological structure were addressed, and the most important are [9-11]. The rock mass structure in the region is carboniferous, mainly built of limestone of the upper Cretaceous age-Santonian. Santonian limestone $-\mathrm{K}_{2}{ }^{3}$ - is thick-bedded, of blocky mass type, and rarely has inserts of laminated limestone or dolomite. According to petrographic classification, limestone is mostly of calcareous composition and only partially bioaccumulated. The percentage of calcareous compounds is high, up to $99 \%$. Biogenic compounds are mainly contained in the fragments. Rock mass, depending on biogenic percentage, was classified as either wackestone or floatstone [3]. 
Geological mapping on the terrain's surface revealed several rock outcrops of blocky type limestone with rock mass structural elements not completely clear [12]. Photographs of two observation points are shown in Figure 3.

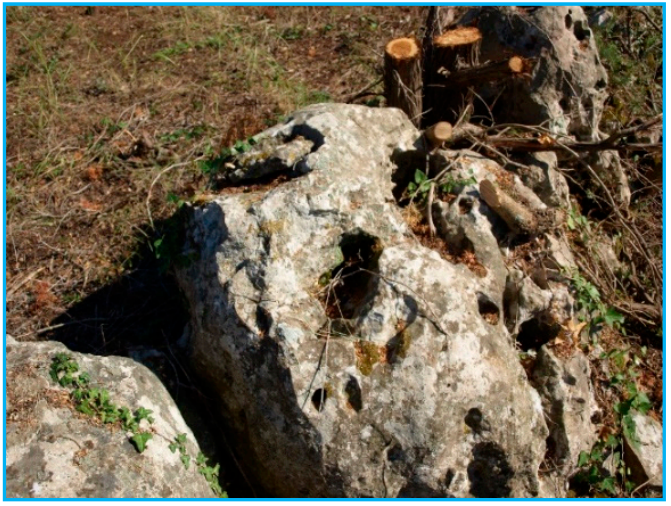

(a)

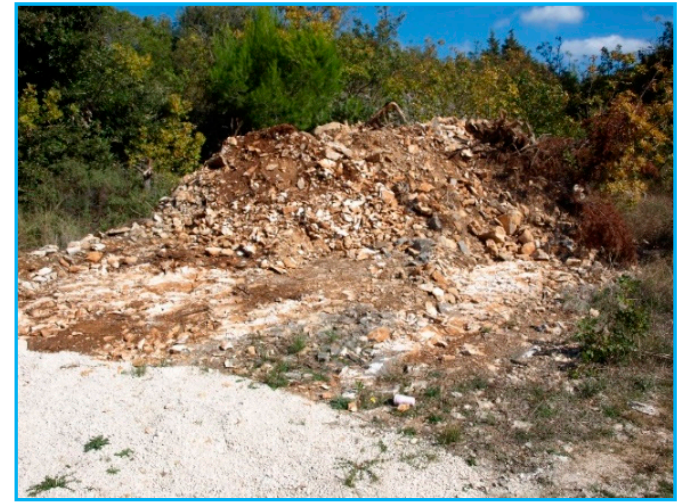

(b)

Figure 3. (a) Rock mass surface outcrops of karstified thick-bedded to blocky type limestone; (b)

Surface outcrop of thin-layered clayey limestone identified on the plot.

Structural properties of rock mass, as recorded from the surface, are depicted on the engineering geological map in Figure 4.

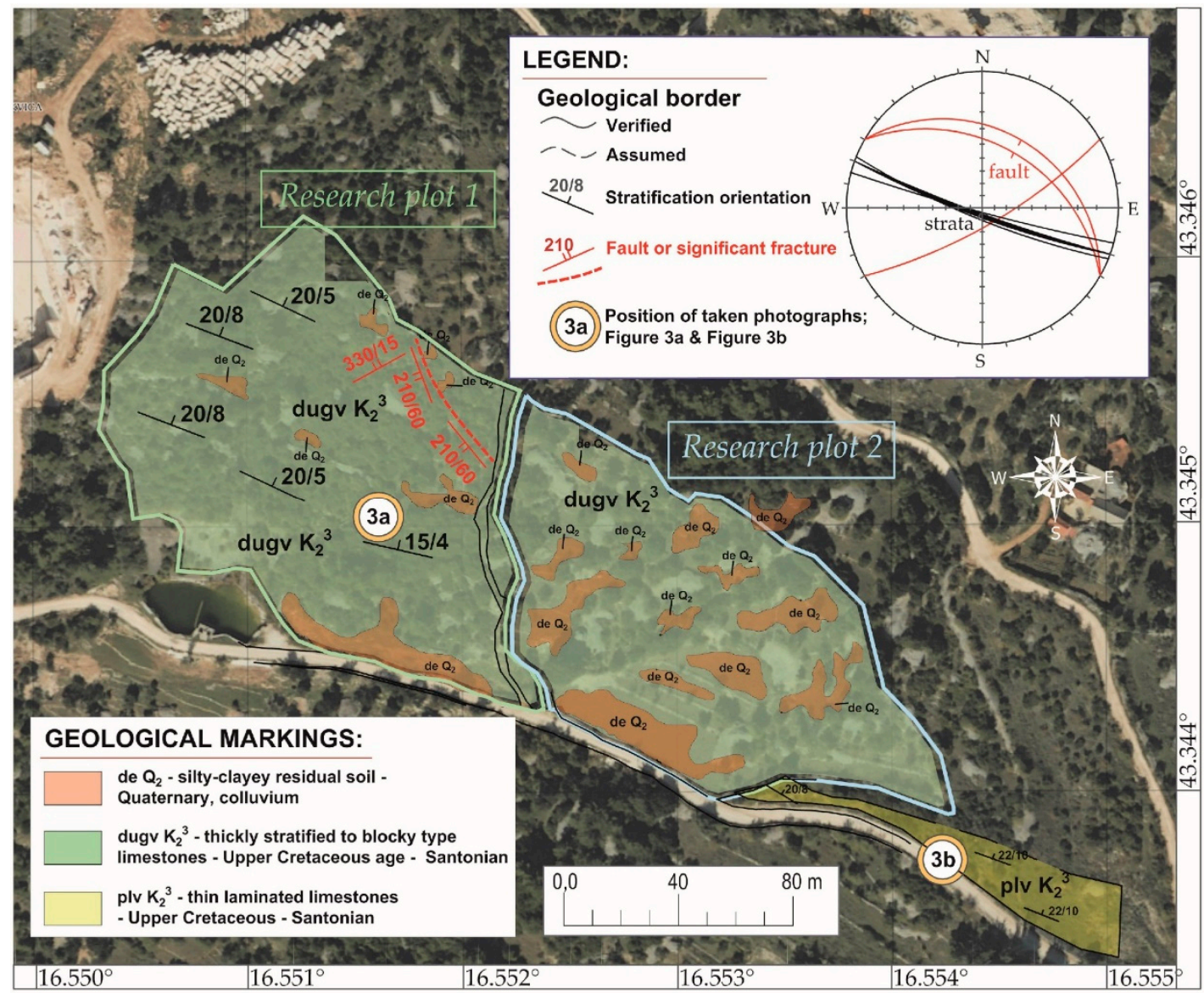

Figure 4. Engineering geological map of the investigated area. The majority of surface visible rock mass structural elements on rock outcrops were recorded on Research Plot 1 . Observed fault position is also depicted on the map. 
The stratification plane (SS) is almost horizontal, just slightly inclined towards the Northeast-direction azimuth $15-20^{\circ}$, inclination $5-15^{\circ}$. Axial planes (AR), although unclearly expressed because of blocky rock mass bedding, have a general direction $200^{\circ} / 80^{\circ}$. Planes perpendicular to the structural axis $(\mathrm{b})$ have direction $110^{\circ} / 80^{\circ}-85^{\circ}$. It needs to be remarked that only a few surface outcrops of blocky type limestone $\left(\mathrm{dugv}_{2}{ }^{3}\right)$ are visible on Research Plot 1 of the investigation area, Figure 3a. On Research Plot 2 none of the named stone could be observed. On Research Plot 2, quaternary deposits are also present (deQ2) and on the far southeast, a relatively wide zone of thin laminated clayey limestone ( $\mathrm{plv} \mathrm{K}_{2}{ }^{3}$ ) was also identified (Figure 3b). On the eastern border of Research Plot 1 , fault zone was registered which could be observed along the $40 \mathrm{~m}$ long line. The fault strike is inclined towards the southwest with an inclination of $55^{\circ}-60^{\circ}$. Fault planes and adjoining crack orientations are $220^{\circ} / 55^{\circ}-60^{\circ}$. The fault planes match the orientation of axial planes (AR). Perpendicular to the axial planes, perpendicular planes to the structural axis (b) could be singled out with the direction $330^{\circ} / 15^{\circ}-30^{\circ}$.

The range of the measured inclinations is a result of extremely karstified surface conditions and superficial karst topography. The structural geological rock mass elements observed on the surface of the investigation area are shown in Table 1. Measurements were conducted on eleven observation points, of which eight had visible stratification planes and three had visible crack orientations.

Table 1. Summary of measured rock mass structural elements.

\begin{tabular}{ccc}
\hline Structural Element & Azimuth of Plane Inclination & Inclination \\
\hline Stratification plane SS & $15^{\circ}-20^{\circ}$ & $5^{\circ}-15^{\circ}$ \\
\hline Axial plain AR & $220^{\circ}$ & $60^{\circ}$ \\
\hline Perpendicular to axis b & $330^{\circ}$ & $15^{\circ}-30^{\circ}$ \\
\hline
\end{tabular}

Besides the described lithology member of Santonian limestone, slightly transported colluvium-residual soil of brown-red silty clay was also identified on the site-terra rossa.

In the hydrogeological sense, the investigated area is poor with groundwater. Two water reservoirs were found on the site which are used for watering in local farming.

\section{Geophysical Investigations}

Several geophysical techniques were used to identify deeper rock quality apart from visible geological elements observable from the surface. In this preliminary phase, boreholes were not considered because of disadvantages such as expenses, limited data and damage to the study area, and because they would have taken a relatively long time to execute. Four surface geophysical methods were available, and each method was evaluated for its advantages and disadvantages according to the target type of the study area [13].

\subsection{Georadar (GPR)}

Rock quality could be well investigated using electromagnetic techniques. Electromagnetic waves propagate through the medium of blocky limestone, thus reflecting inhomogeneity with different parameters such as layer boundaries. The received signal, however, in addition to the reflected wave, also contains a direct wave that travels the shortest distance, directly from the transmitting to the receiving antenna. Therefore, the receiver's output signal is a combination of the transmitter's pulse followed by reflected pulses. This transmitter's pulse should be used as a starting point for estimating a delay time of reflected signals for the purpose of determining the target's depth. The section of the recorded GPR-2 radargram is shown in Figure 5. Dielectric permeability equal to six was chosen for a time-depth conversion procedure in blocky limestone [14]. Values are primarily controlled by water saturation and, secondarily, by porosity and mineralogy. Differences in the dielectric constant must be greater than two to produce reflections that can be recorded above background noise. 


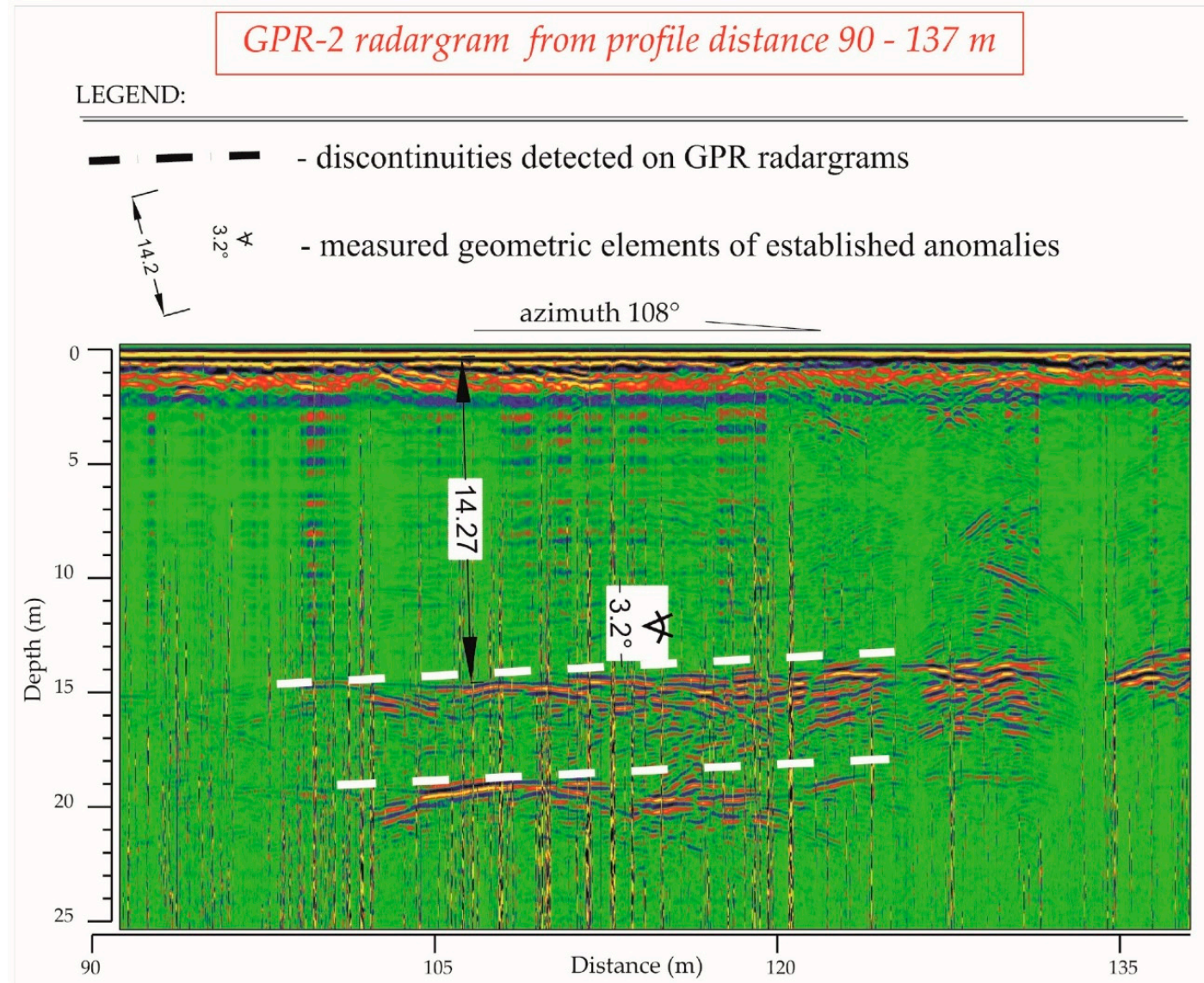

Figure 5. Radargram recorded along line GPR-2 with interpreted stratification planes observed along the profiles. Measured inclination of $3^{\circ}-5^{\circ}$. Measured dip corresponds well to the observations on surface rock outcrops.

Field GPR profiling was done using a ZOND12e GPR system (Radar System, Inc. Latvia) and a $300 \mathrm{MHz}$ shielded antenna. Acquiring was done with the Prism2 software. Only a high-pass real-time filter was used for trace recording. The filter's cutoff frequency is automatically set to attenuate low-frequency noise, which arises while the antenna is crossing the rough terrain. The trace stacking selected was two, with 512 samples per trace. The signal was recorded without any gain. Gain is used only while displaying the data in the form of the radar profile. Pulse delay changes the sounding signal's position within the sounding time range. Values for shown recordings are 300 to $500 \mathrm{~ns}$, depending on the chosen resolution depth. It is important to ensure an appropriate setup at the first start of georadar, with a given antenna and for the given range value. Distance of profile is measured by the wheel attached to the antenna.

It is important to understand GPR images, and the limits of GPR imaging the difference in dielectric constants. It is evident that the influence of changed porosity is more pronounced when water occupies the pores. As shown in Figure 5, visible bedding planes must exceed at least 35\% porosity differences to obtain a high reflection coefficient to show sharp contact, as in the figure.

Limestone rock mass has an average propagation velocity of $\sim 0.3 \mathrm{~m} / \mathrm{ns}$, while the water or air in cracks between stratum contact surfaces have velocities of either $0.11 \mathrm{~m} / \mathrm{ns}$ or $0.03 \mathrm{~m} / \mathrm{ns}$, thus giving high velocity contrast [15]. High contrast, in the example, produces a good quality GPR radargram. Radargram traces contain few phases of waves arrived on the receiver: first arrivals of reflected waves passed only once through the medium, and secondary waves in the form of direct or refracted waves. The special shape of the emitted pulse wave makes it possible to detect position within the reflected signal, and it is used to determine zero ground level for ground-coupled antennas. 
Figure 6 shows an example of a good quality GPR radargram, together with the corelating photography and visible planes of stratum, parting as photographed on the neighboring open mine artificial cutting line.

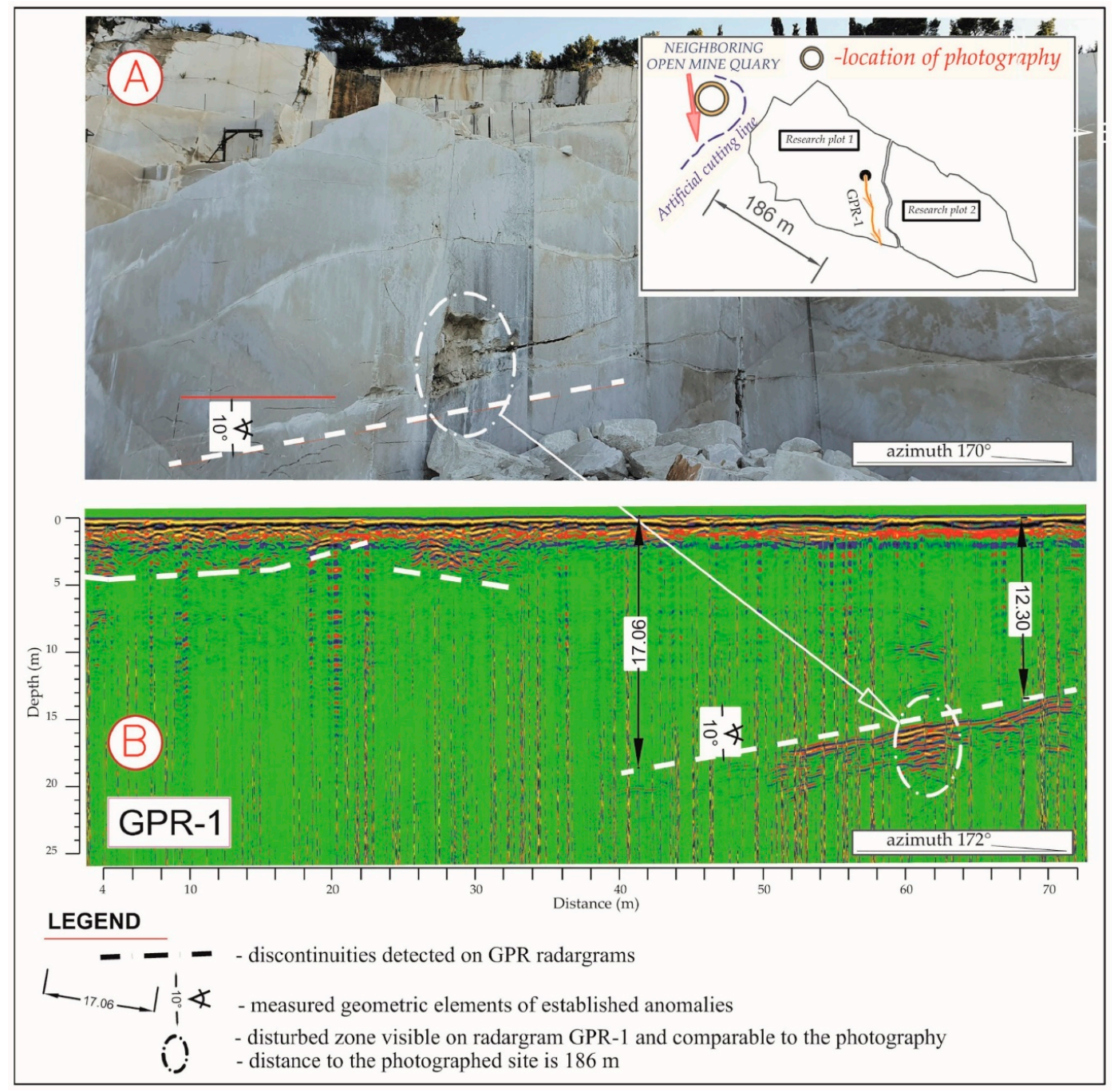

Figure 6. Photographs of stratum boundaries as seen on the open quarry artificial cutting line, together with the georadar (GPR) radargram recorded on the investigation site at the approximately same profile direction azimuth.

Based on the presented results, georadar has been verified as a good-quality investigation method for the designated purpose of assessing the acceptability of rock mass for the exploitation of the architectural structural stone.

\subsection{Electrical Resistivity Tomography}

The advantage of the 2D electrical resistivity method is its ability to study complex subsurface structures. It has a good ability to detect groundwater or, more importantly, changes in moisture content. It is a relatively economical method, portable, and capable of imaging a kilometer-long single profile. Moisture content in rock mass is a result of water distribution through fissures and cracks, so the electrical resistivity could be directly correlated to the rock mass quality. The importance of choosing proper measuring arrays is critical for a good interpretation of the subsurface [16]. A Wenner array was used as it has good vertical resolution. That is, horizontal anomalies could be detected with high resolution. Other options for resistivity imaging are dipole-dipole and Wenner-Schlumberger, 
pole-pole, etc. [17]. A GF Instruments, s.r.o ARES multielectrode resistivity imaging system with active multi-electrode cables was used as an electrical resistivity imaging system on the site.

On site, two parallel ERT profiles were recorded, each with a length of $277.3 \mathrm{~m}$, using a 48 -electrode array. Figure 7 shows inverse model resistivity sections of the two recorded ERT profiles. Collected ERT data on the site were interpreted using RES2DINV 2-D inversion software, which uses the rapid least squares inversion method to model the final resistivity section $[18,19]$.

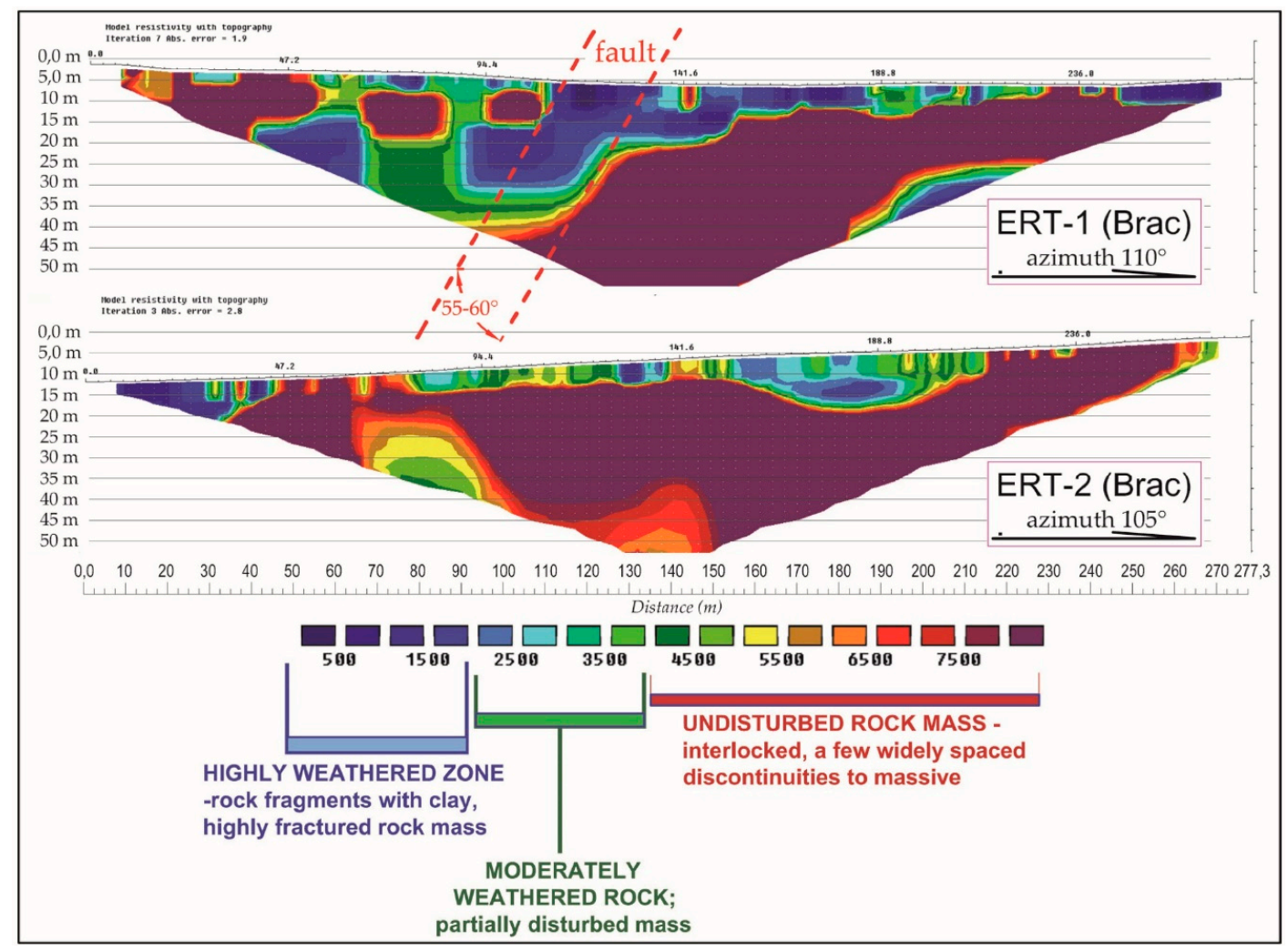

Figure 7. Inverse model resistivity sections of profiles ERT-1 and ERT-2. The resistivity scale is divided according to the rock mass degree of weathering.

On the basis of measured electrical resistivity values at the ERT profiles, conclusions on the rock quality were derived. According to resistivity ranges (Figure 7), three lithological rock mass types could be differentiated. Lower electrical resistivity values, in the range of 500-2000 $\Omega \mathrm{m}$, correspond to a highly weathered rock mass. Highly weathered rock mass is distributed along the profiles at shallow depths as a result of surface weathering processes (up to $5 \mathrm{~m}$ ). Additionally, a very important large area of highly weathered rock is visible on the west area of profile ERT-1 (Figure 7). The same area visible on the ERT profile corresponds to the observed fault on the engineering geological map (Figure 4). The electrical resistivity profile reveals the real magnitude of the fault area, covering a large part of the ERT profile. The depth of fault influence on the rock quality is registered as deep as is visible with the ERT profile resolution depth. This investigation area is not suitable for architectural structural dimension block mining. As will be shown later, electrical resistivity imaging will be a base for creating engineering geologic sectional profiles.

\subsection{Seismic Profiling}

The construction of a seismic velocity model is a primary use of seismic profiling. Seismic wave propagation velocities are influenced by internal rock mass conditions, that is, fluid saturation, fissures, and crack distribution. Seismic velocity in rock formations also depends on mineral composition, the granular nature of the rock matrix, cementation, porosity, fluid content and geological pressure, as 
well as geological age [20]. Both seismic velocities (Vp \& Vs) are dependent on rock mass density. Relationships between seismic velocities and rock mass densities have been established in the literature through extensive laboratory and field experimentation [21,22]. Shear wave seismic velocity is directly related to shear modulus at the small-strain deformation. Therefore, compressional and shear wave propagation velocity is the direct result of stiffness of the medium and/or damping profile [23].

\subsubsection{Shallow Refraction Seismic (SRS)}

The simplest principle for observing propagation velocity is to measure the delay time between the seismic source and fixed receivers positioned in line. Refraction seismic profiling uses the travel time of active seismic impulses, the first arrivals of the wave refracted from the contact of the two media. The precision of the impulse time arrivals is the precision of measurement, as well as the obtained seismic profile. Seismic refraction is applicable on soil with increasing seismic velocity profile with depth [24]. At the site, four shallow refraction seismic (SRS) profiles were recorded with 24 geophones in line, spaced $3 \mathrm{~m}$. All the recordings were done using a Geometrics Inc., Geode seismograph. First time arrivals are picked from the recorded seismographs. Interpretation was done using the Rayfract 2.63 software pack-Intelligent Resources Inc.

The stated condition is necessary for the wave to refract on the contact surface of two materials. With higher seismic velocity contrast, better detection of the contact plane is obtained. Figure 8 displays two seismic refraction profiles recorded at the site, showing different weathering zone depths and rock mass qualities. Geophysical properties of the weathering zone are defined according to classification of the carbonate rock mass by Novosel [25]. Weathering zones corelate to the $4^{\text {th }}$ and $5^{\text {th }}$ rock categories, with geophysical parameters ranging, for seismic waves, $V_{p}=900-2000 \mathrm{~m} / \mathrm{s}, \mathrm{V}_{\mathrm{s}}=400-1000 \mathrm{~m} / \mathrm{s}$, and for electrical resistivity 500-2000 $\Omega \mathrm{m}$.

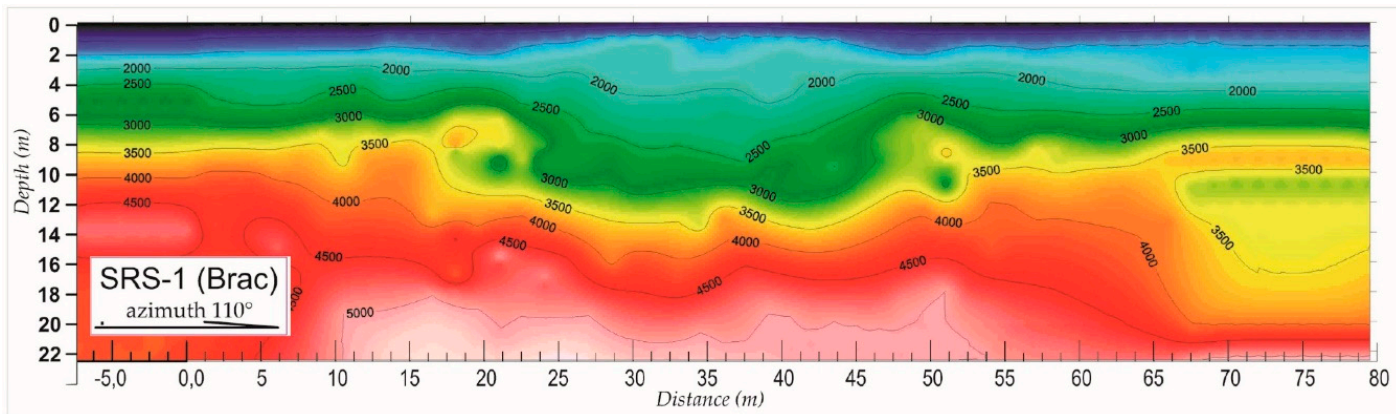

(a)

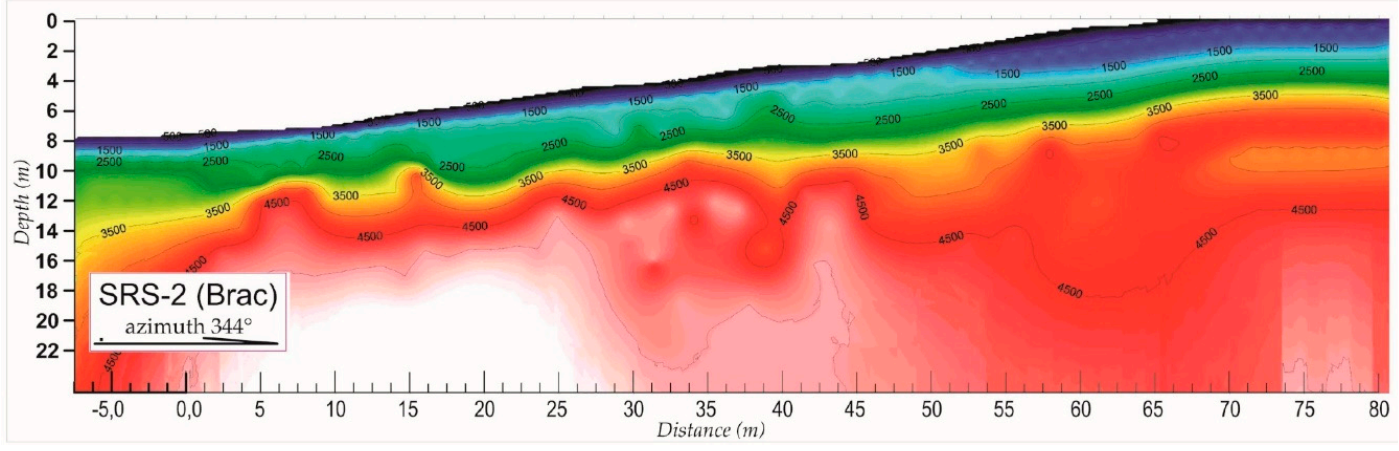

(b)

Figure 8. Models of compressional wave velocities $\left(\mathrm{V}_{\mathrm{p}}\right)$, interpreted from shallow refraction seismic (SRS). (a) Deeper weathering zones could be observed on the central part of the seismic profile $\mathrm{V}_{\mathrm{p}}=2000-3500 \mathrm{~m} / \mathrm{s}$; (b) Refraction seismic profile, with rock quality layers following slope inclination and bedrock compressional wave velocity higher than $V_{p}=4500 \mathrm{~m} / \mathrm{s}$. 


\subsubsection{Multichannel Analysis of Surface Waves (MASW)}

The application of the multichannel analysis of surface waves (MASW) method was appropriate for the measurement of shear wave velocities as an alternative to the shear-wave refraction method. The shear wave refraction method does not work well in noisy areas. It takes more time for data acquisition and requires excessive post-acquisition processing compared to the MASW method [23]. Data acquisition for refraction and MASW seismic surveys were conducted along the same seismic lines, utilizing $4.5 \mathrm{~Hz}$ geophones. In common stratigraphic conditions, the surface wave propagation is dominated by the fundamental mode. In cases with a very strong velocity contrast between layers at shallow depths, higher modes may be excited and may need to be considered in inversion analyses [26]. Profiles with a gradual increase in shear wave velocity with depth are called normally dispersive profiles. Figure 9 shows the results of shear wave velocities at the position of profile Seis- 1 from the interpretation of the fundamental mode.
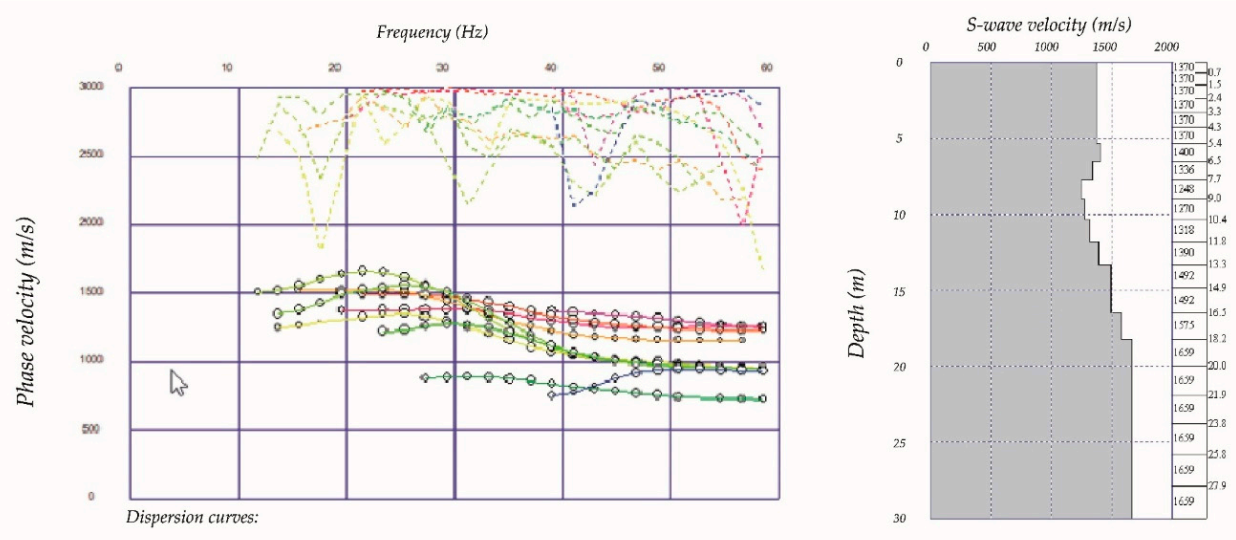

(a)

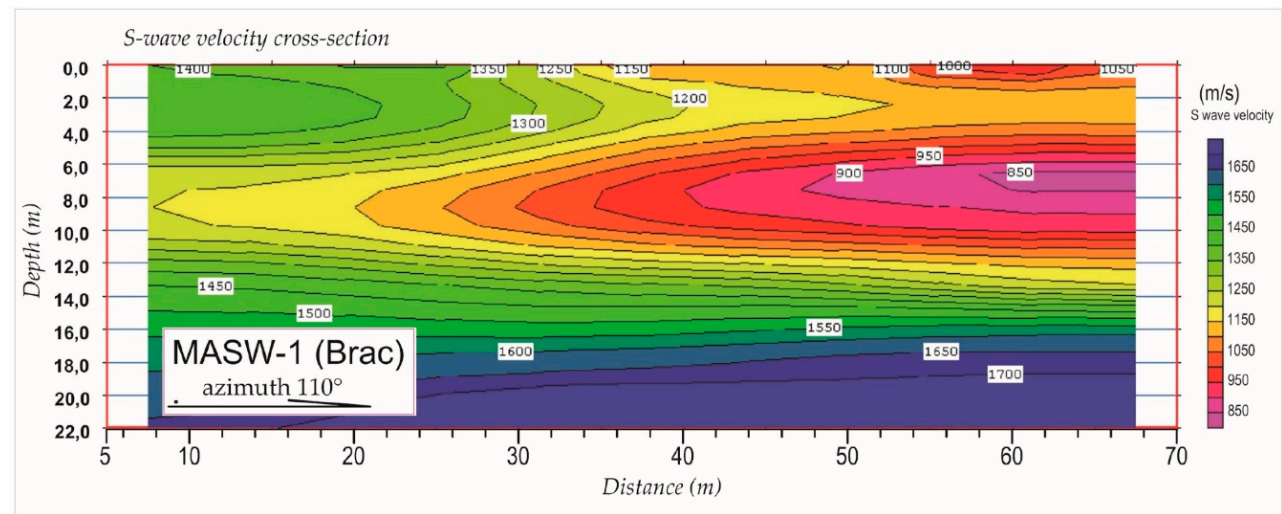

(b)

Figure 9. Shear wave velocity model obtained by the multichannel analysis of surface waves (MASW) seismic method. (a) Phase velocity curves with corresponding signal-to-noise curves on the left side and corresponding shear velocity 1D profile on the right side. (b) S-velocity model obtained using the Seisimager CMP technique, OYO Corporation.

The surface wave profiles (MASW) show more averaged images than the ones obtained by shallow refraction seismic (SRS) profiling. This is due to the fact that two methods and their propagation velocities are governed by different stiffness moduli: longitudinal and shear. Compressional waves respond to the presence of pore fluids and saturation overall, while shear waves' response to these is negligible, for the reason that fluids do not have shear resistance.

The MASW data were used to generate 2D shear wave velocity (Vs) profiles. Recorded seismograms were processed by widely used MASW techniques for picking amplitude maxima in 2D spectral 
representations of the wavefield [26]. The MASW 2D Vs profiles and the refraction SRS profiles compared well in mapping the rock mass property that varies with changes in conditions such as crack density. The results confirmed that the MASW method can be an alternative to the shallow seismic refraction method when the near-surface conditions allow. It is good practice to discard traces with lower values of signal-to-noise ratio.

\section{Results}

Comprehensive data were gathered at the investigation site, which were then used to distinguish parts of the terrain more or less suitable for dimension stone mining. Based on the obtained geophysical data and engineering geological mapping, two geological sections with representations of rock quality in three categories were created.

The area on the geophysical profile with the highest change in parameter gradient is considered to be a fault contact. If there is a sharp transition from a compact environment to a less compact one, a fault contact is assumed, since such a sharp transition cannot have a character other than a tectonic one, especially in such a homogenous environment.

Using the process shown in Figure 10, two engineering geological cross-sections were created along the main geophysical lines of ERT-1 and ERT-2 profiles and are shown in Figure 11. Derived categories in Figure 11 represent decisive criteria for considering the acceptability of rock mass structural elements for the extraction of dimension stones [27]. This criterion could also be used for quick assessment of target areas in that region.

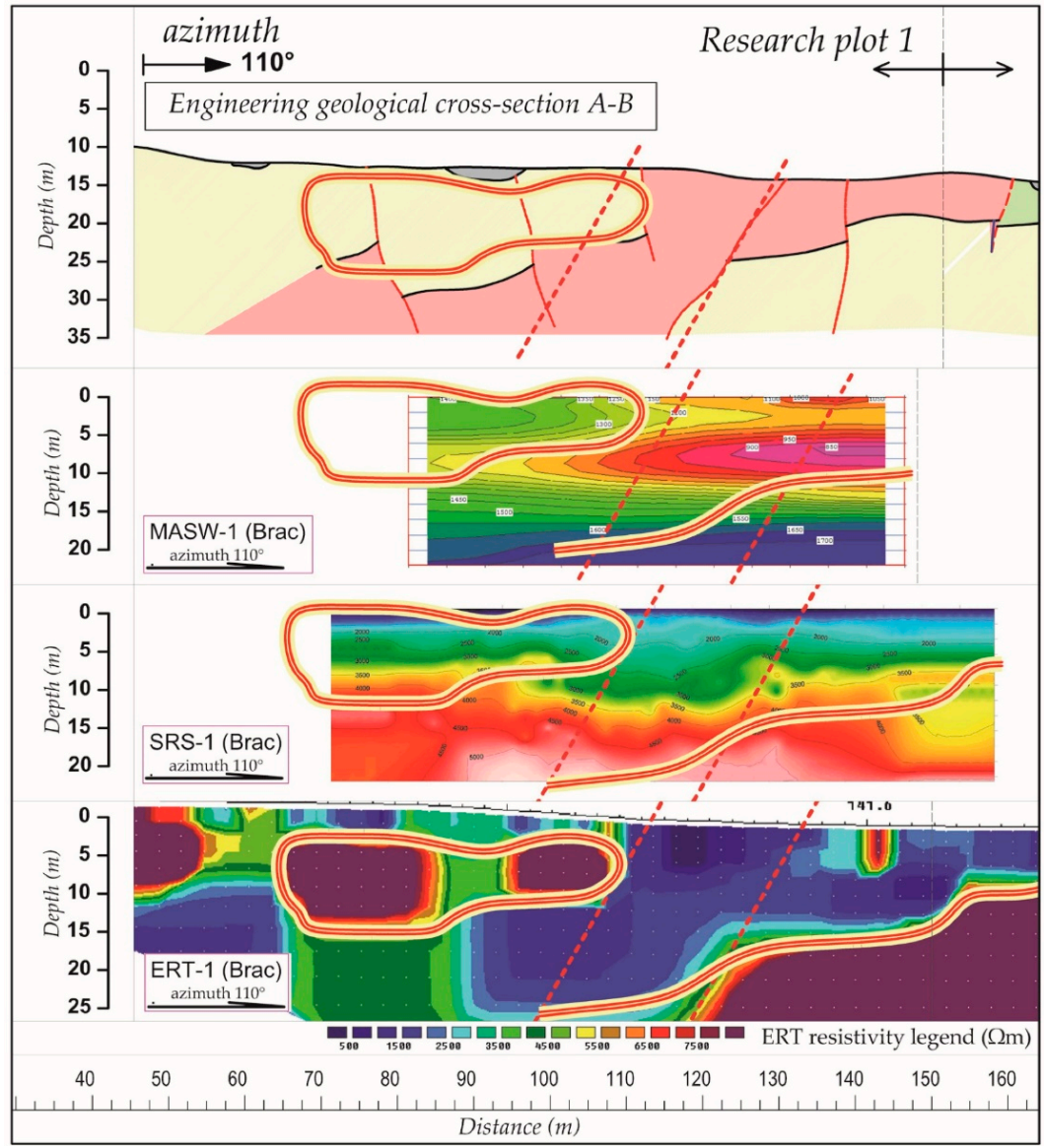

Figure 10. The process of the geophysical profiles overlaying to create the composite geophysical data needed to create the engineering geological profile. Boundary elements lines are shown on top of each geophysical profile to visually depict comparable zones between profiles. The top image is the resulting engineering geological cross-section of the process. 

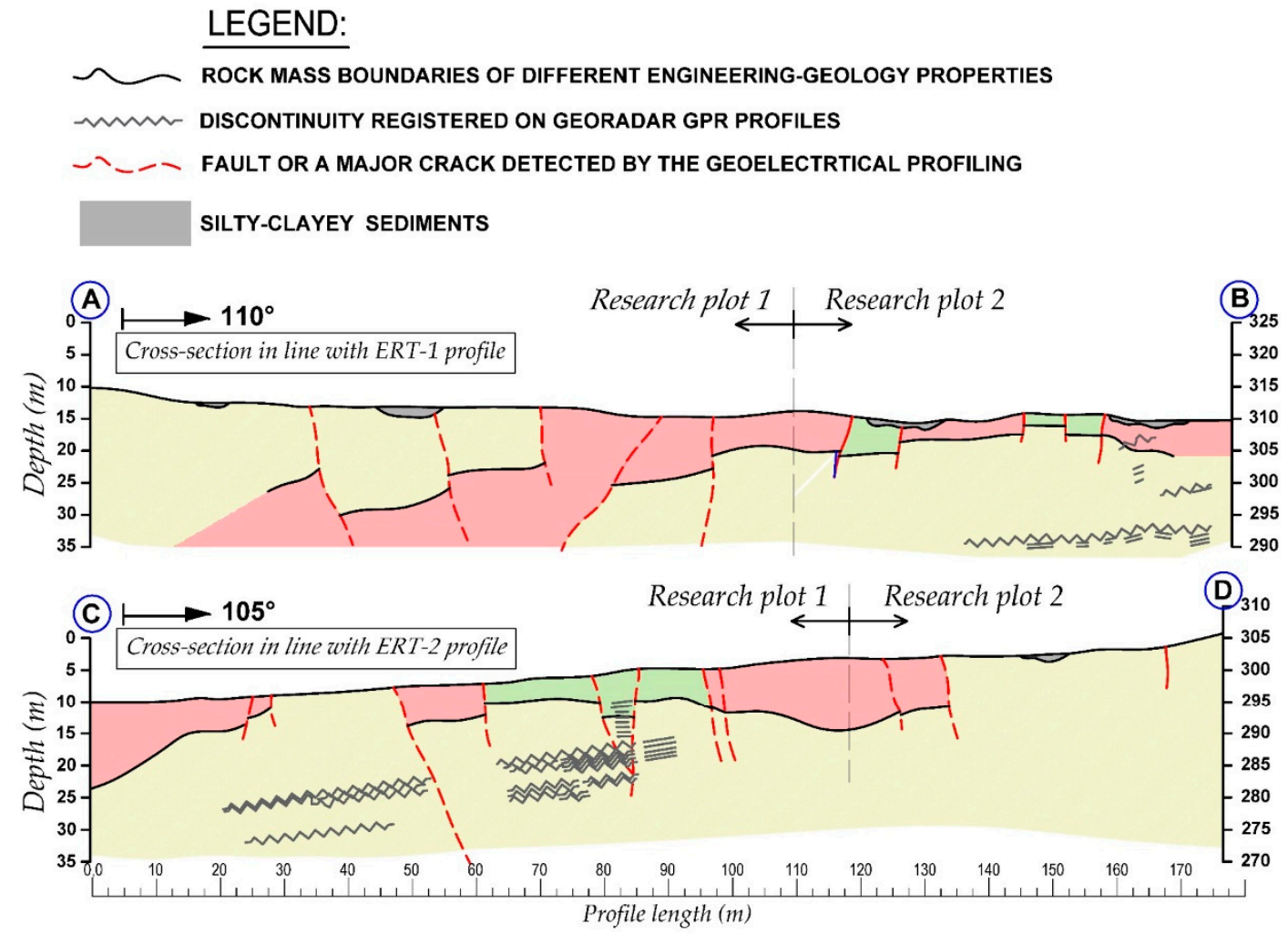

\begin{tabular}{|c|c|c|c|c|c|}
\hline \multicolumn{6}{|c|}{ ENGINEERING GEOLOGICAL ROCK PROPERTIES } \\
\hline \multirow{3}{*}{$\begin{array}{l}\text { COLOUR } \\
\text { MARKINGS }\end{array}$} & \multicolumn{3}{|c|}{ GEOPHYSICAL PROPERTIES } & \multirow{3}{*}{ KARSTIFICATION } & \multirow{3}{*}{$\begin{array}{c}\text { ROCK MASS } \\
\text { SUITABILITY FOR } \\
\text { EXTRACTION OF } \\
\text { DIMENSION } \\
\text { STONES } \\
\end{array}$} \\
\hline & \multicolumn{2}{|c|}{ SEISMIC WAVE VELOCITIES $(\mathrm{m} / \mathrm{s})$} & \multirow{2}{*}{$\begin{array}{c}\text { ELECTRICAL } \\
\text { RESISTIVITY }(\Omega \mathrm{m})\end{array}$} & & \\
\hline & $\operatorname{SHEAR}\left(v_{S}\right)$ & COMPRESS. $\left(v_{P}\right)$ & & & \\
\hline & $1500-3000$ & $3000-5000$ & $3500-7500$ & $\begin{array}{l}\text { COMPACT LIMESTONE } \\
\text { ROCK MASS NOT } \\
\text { KARSTIFIED, MALL } \\
\text { FISSURES }\end{array}$ & $\begin{array}{c}\text { ROCK MASS IS SUITABLE } \\
\text { FOR MINING THE } \\
\text { MASSIVE BLOCKS }\end{array}$ \\
\hline & $1000-2000$ & $2000-3500$ & $2000-3500$ & $\begin{array}{l}\text { LESS COMPACT ROCK } \\
\text { MASS MEDIUM } \\
\text { FRACTUED AND } \\
\text { KARSTIFIED }\end{array}$ & \begin{tabular}{|c|} 
ROCK MASS OF \\
QUESTINABALE \\
PROPERTIES FOR A \\
DESIGNATIE PURPOSE
\end{tabular} \\
\hline & $300-1000$ & $500-2000$ & $500-2000$ & $\begin{array}{l}\text { ROCK MASS } \\
\text { SIGNIFICANTLY } \\
\text { FRACTUED AND } \\
\text { KARSTIFIED }\end{array}$ & \begin{tabular}{|l|} 
ROCK MASS COULL NOT \\
BE USED AS AN \\
ARHITECUURAL \\
STRUCTURAL STONE
\end{tabular} \\
\hline
\end{tabular}

Figure 11. Final engineering geological sections derived from the geophysical data along the investigation site. Rock mass quality regarding dimension block mining is represented in the table by three categories. For each rock mass category, values of geophysical parameters are defined.

\section{Discussion}

Engineering geologic mapping from the surface of the terrain gives quality data about rock mass structural elements, like discontinuity systems' orientations and fault positions. However, they could not provide decision-making details concerning deeper rock mass quality, which was the main objective of this research. Geological investigations often are accompanied by exploratory drilling, which has its drawbacks. Borehole investigations are expensive and long term. It is a kind of point test, so a lot of small defects are missed by drilling. This is why the geophysical site investigation was used on a case study area.

In the applied geophysics, is well known that for assessing the adequacy of the geophysical method, geophysical contrasts at the investigated site have to be understood. It is also important to evaluate site characteristics, regarding the penetration depth and resolution of the geophysical method. As well, it is also very important to calibrate acquired data by means of geological/geotechnical data. 
The reported case study shows a successfully employed geophysical/geological investigation with the purpose of determining the suitability of rock mass for dimension stone mining.

Radargrams are good visual aids to geological mapping, because georadar profiling reveals bedding planes. Therefore, georadar results can be very useful in exploration of the architectural structural stone.

Geoelectrical tomography has proven to be a very good method for detecting fault zones. Profile ERT-1 revealed a wide and deep influence of faults on rock quality, thus revealing a part of terrain not suitable for the designated purpose. The fault area detected by surface mapping is clearly visible on the geoelectrical and seismic profiles, as depicted in Figures 7, 8a and 10. ERT profiles are also suitable for the assessment of limestone rock quality. It was shown that electrical resistivity values in the range of 500-3000 $\Omega \mathrm{m}$ correspond to a highly to moderately weathered rock mass, which has questionable properties for mining massive blocks.

Geophysical seismic investigations directly reflect rock mass mechanical properties. In general, a lower seismic velocity indicates a very fragmented rock mass with poorer mechanical properties. Higher seismic velocities indicate a solid rock mass which is more suitable for dimension stone exploitation.

Correlating the observed rock mass structural elements to the measured geophysical properties resulted in a categorization of rock mass suitability for dimension block extraction. Parameters were defined for each category as depicted in Figure 11. Rock mass of blocky, thick-bedded limestone, in the investigated area of the island Brač, is suitable for architectural structural stone mining if in general it has electrical resistivity higher than $3000 \Omega \mathrm{m}$, seismic compressional wave velocity higher than $3000 \mathrm{~m} / \mathrm{s}$ and shear wave velocity higher than $1500 \mathrm{~m} / \mathrm{s}$. Lithological characterization is done through geological surveys [28]. The defined parameters are key for the structural characterization of the prospective dimension stone locations.

\section{Conclusions}

Dimension stone mining is important from the perspective of the island of Brač's industry. For the optimum results of dimension stone extraction, it is important to understand the physical properties of the rock mass. Structural geological surveys give insight, with valuable data on the orientation of bedding plains as well as their discontinuity geometry. The density of discontinuities and local variations in rock quality govern decisions about site acceptability for the extraction of natural dimension stones. As shown in this paper, this can be assessed by geophysical survey.

Borehole investigations are expensive, and, also, borehole patterns cannot economically be spaced out to detect all discontinuities and fractures. Many small defects are missed by drilling.

Geophysical site investigations on a case study area resulted in rock mass categorization regarding its acceptability for block extraction. The used geophysical methods and tests have been proven on the site as useful tools for site characterization.

Electrical resistivity tomography revealed the extent of fault zones mapped from the surface. Disturbed rock mass along the fault enables water infiltration through cracks and fissure systems, which effectively changes electrical resistivity, thus producing good resistivity contrast. The electrical resistivity method was used as the base information for producing engineering geologic section profiles. Another advantage of electrical resistivity profiling is that profiles can also extend in a long line, so a large area of terrain can be covered. Changes in electrical resistivity reflect even minor change in moisture content due to small fissures inside monolithic blocks. It has been found that a limestone rock mass with resistivity higher than $3000 \Omega \mathrm{m}$ is good for producing dimension stones.

Seismic refraction complements resistivity profiles and also directly reflects mechanical properties. Resolution of shallow refraction seismic is high, contouring bedrock with great detail. The surface wave profiles show more averaged velocity images, without the sharp boundaries of refraction profiles.

Georadar profiling only revealed bedding planes with widely parted stratification planes, and for that reason it can be used as a good visual aid to geological mapping. 
It is planned to verify the result of this investigation with structural geological boreholes at two positions. The investigation result could then be calibrated to borehole logs, as well as the provisions in this paper additionally acknowledged.

Author Contributions: Conceptualization, J.J.; Formal analysis, K.G.; Investigation, S.S.; Methodology, J.J.; Project administration, S.S.; Validation, F.D.; Writing - original draft, K.G. All authors have read and agreed to the published version of the manuscript.

Funding: The APC was funded by Faculty of Geotechnical Engineering, University of Zagreb, Hallerova aleja 7, Varaždin (42000), Croatia.

Acknowledgments: Authors are very grateful to PhD Janislav Kapelj for assistance with engineering geological mapping.

Conflicts of Interest: The authors declare no conflict of interest.

\section{References}

1. Crnković, B.; Jovičić, D. Dimension stone deposits in Croatia. Rudrasko-geološko-naftni zborik 1993, 5, $139-163$.

2. Zhang, L. Estimating the Strength of Jointed Rock Masses. Rock Mech. Rock Eng. 2010, 43, 391-402. [CrossRef]

3. Gusić, I.; Jelaska, V. Stratigrafija Gornjokrednih Naslaga Otoka BRACA u Okivu Geodinamske Evolucije. Jadranske Karbonatne Platforme; Jugoslavenska Akad. Znanosti Umjetnosti: Zagreb, Yugoslavia, 1990.

4. Kovačević, M.S.; Marčić, D.; Gazdek, M. Application of geophysical investigations in underground engineering. Tech. Gaz. 2013, 20, 1111-1117.

5. Mosch, S.; Nikolayew, D.; Ewiak, O.; Siegesmund, S. Optimized extraction of dimension stone blocks. Environ. Earth Sci. 2011, 63, 1911-1924. [CrossRef]

6. Ashmole, I.; Motloung, M. Dimension Stone: The Latest Trends In Exploration And Production Technology. South. African Inst. Min. Metall. 2008, 1, 35-70.

7. Luodes, H.; Selonen, O.; Pääkkönen, K. Evaluation of dimension stone in gneissic rocks-A case history from southern Finland. Eng. Geol. 2000, 58, 209-223. [CrossRef]

8. Lu, P.; Latham, J.-P. Developments in the Assessment of In-situ Block Size Distributions of Rock Masses. Rock Mech. Rock Eng. 1999, 32, 29-49. [CrossRef]

9. Marinčić, S.; Korolija, B.; Majcen, Ž. Osnovna Geološka Karta SFRJ list Omiš, m 1:100000, K 33-22 [Base Geological Map page Omišl; Beograd: Institut za geološka istraživanja: Zagreb, Croatia, 1976.

10. Marinčić, S.; Korolija, B.; Mamužić, P.; Magaš, N.; Majcen, Ž.; Brkić, M.; Benček, Đ. Tumač za list Omiš K33-22; Beograd: Institut za geološka istraživanja: Zagreb, Croatia, 1977; Volume 1, pp. 1-45.

11. Marković, S. Hrvatske mineralne sirovine, Mineral Resources in Croatia; Institut za geološka istraživanja, Zavod za geologiju: Zagreb, Croatia, 2002; ISBN 953-6907-01-1.

12. ISRM. The Blue Book: "The Complete ISRM Suggested Methods for Rock Characterization, Testing and Monitoring: 1974-2006"; Ulusay, R., Hudson, J.A., Eds.; ISRM Turkish National Group: Ankara, Turkey, 2007; ISBN 978-975-93675-4-1.

13. Strelec, S.; Mesec, J.; Grabar, K.; Jug, J. Implementation of in-situ and geophysical investigation methods (ERT \& MASW) with the purpose to determine 2D profile of landslide. Acta Montan. Slovaca 2017, 22, 345-358.

14. Martinez, A.; Byrnes, A.P. Modeling dielectric-constant values of geologic materials: An aid to ground-penetrating radar data collection and interpretation. Curr. Res. Earth Sci. 2001, 247, 1-16.

15. Musil, M.; Maurer, H.R.; Green, A.G. Discrete tomography and joint inversion for loosely connected or unconnected physical properties: Application to crosshole seismic and georadar data sets. Geophys. J. Int. 2003, 153, 389-402. [CrossRef]

16. Pazzi, V.; Morelli, S.; Fanti, R. A Review of the Advantages and Limitations of Geophysical Investigations in Landslide Studies. Int. J. Geophys. 2019, 2019, 1-27. [CrossRef]

17. Abdul, I.; Alwan, K. Comparison between Conventional Arrays in 2D Electrical Resistivity Imaging Technique for Shallow Subsurface Structure Detection of the University of Technology. Eng. Technol. J. 2013, 31, 1817-1824.

18. Loke, M.H.; Barker, R.D. Rapid least-squares inversion of apparent resistivity pseudosections by a quasi-Newton method1. Geophys. Prospect. 1996, 44, 131-152. [CrossRef] 
19. Geotomo Software PLY LTD RES2DINVx64 ver 4.09, Software Manual; Rapid 2-D Resistivity \& IP Inversion Using the Least-Squares Method; Loke, M.H., Ed.; GeoTomo: Houston, TX, USA, 2019; pp. 1-137.

20. Gardner, G.H.F.; Gardner, L.W.; Gregory, A.R. Formation Velocity and Density-The Diagnostic Basics for Stratigraphic Traps. Geophysics 1974, 39, 770-780. [CrossRef]

21. Miller, S.L.M.; Stewart, R.R. The relationship between elastic-wave velocities and density in sedimentary rocks: A proposal. Crewes Res. Rep. 1974, 260-273.

22. Redpath, B.B. Seismic refraction exploration for engineering site investigations. U.S. Army Eng. Waterw. Exp. Stn. 1973, 1-63.

23. Foti, S.; Lai, C.; Rix, G.J.; Strobbia, C. Surface Wave Methods for Near-Surface Site Characterization; CRC Press: Boca Raton, FL, USA, 2014.

24. ASTM. Standard Guide for Using the Seismic Refraction Method for Subsurface, D5777-00; ASTM International: West Conshohocken, PA, USA, 2011; pp. 1-14.

25. Novosel, T.; Tušar, Z.; Mulabdić, M.; Garašić, M.; Koražija, S. Rating of Slope Stability Built of Carbonate Rocks. In Proceedings of the 5. Simpozij Jugoslavenskog Društva za Mehaniku Stijena i Podzemne Radove: Zbornik Radova. Knj. 1; Simović, V., Ed.; Građevinski institut: Split, Croatia, 1980; pp. 185-192.

26. Foti, S.; Hollender, F.; Garofalo, F.; Albarello, D.; Asten, M.; Bard, P.-Y.; Comina, C.; Cornou, C.; Cox, B.; Di Giulio, G.; et al. Guidelines for the good practice of surface wave analysis: a product of the InterPACIFIC project. Bull. Earthq. Eng. 2018, 16, 2367-2420. [CrossRef]

27. Carvalho, J.F.; Henriques, P.; Falé, P.; Luís, G. Decision criteria for the exploration of ornamental-stone deposits: Application to the marbles of the Portuguese Estremoz Anticline. Int. J. Rock Mech. Min. Sci. 2008, 45, 1306-1319. [CrossRef]

28. Hoffmann, A.; Siegesmund, S. Investigation of dimension stones in Thailand: an approach to a methodology for the assessment of stone deposits. Zeitschrift der Dtsch. Gesellschaft für Geowissenschaften 2007, 158, 375-416. [CrossRef]

(C) 2020 by the authors. Licensee MDPI, Basel, Switzerland. This article is an open access article distributed under the terms and conditions of the Creative Commons Attribution (CC BY) license (http://creativecommons.org/licenses/by/4.0/). 